\title{
Antitumor effect of Quercetin on Y79 retinoblastoma cells via activation of JNK and p38 MAPK pathways
}

Haojie Liu and Ming Zhou*

\begin{abstract}
Background: Quercetin (QCT) is a flavonol present in many vegetables, it is proved to show chemo preventive effect against lung, cervical, prostate, breast and colon cancer due to its anti-inflammatory, anti-tumor and anti-oxidant property. Looking into the reported chemo-preventive effect we speculated antitumor activity in retinoblastoma (RB) Y79 cells, we also studied the molecular mechanism for antitumor activity.

Methods: The effect of QCT on Y79 cell viability count was done by cell counting kit, cell cycle distribution, apoptosis studies and mitochondrial membrane potential was evaluated by flow cytometry. Protein expression was done by western blot analysis.

Results: The outcomes of study showed that QCT reduced Y79 cell viability and caused arrest of G1 phase in cell cycle via decreasing the expression levels of cyclin-dependent kinase (CDK)2/6 and cyclin D3 and by increasing the levels of both CDK inhibitor proteins p21 and p27. Apoptosis of Y79 cells mediated by QCT occurred via activation of both caspases-3/-9. Flow cytometry studies showed that QCT caused collapse in mitochondrial membrane potential $(\Delta \psi \mathrm{m})$ in Y79 cells. Western blot studies confirmed that QCT brought about phosphorylation of c-Jun N-terminal kinase (JNK) and p38 mitogen-activated protein kinase (MAPK). We also established that inhibitors of JNK and p38 MAPK suppressed QCT mediated activation of both caspases-3/-9 and subdued the apoptosis of cancerous Y79 cells.
\end{abstract}

Conclusion: All the results of the study suggest that QCT induced the apoptosis of Y79 cells via activation of JNK and p38 MAPK pathways, providing a novel treatment approach for human RB.

Keywords: Quercetin, Retinoblastoma, Apoptosis, c-Jun N-terminal kinase, p38 mitogen-activated protein kinase

\section{Background}

Retinoblastoma (RB) has been reported to be one of the most occurring malignancies of intraocular cavity in small children's. It has been reported to affect about every 1 in 15,000 children worldwide [1]. The etiology of the disease is associated with alterations in the $R B$ tumour suppressor gene (RB1) of the retinal progenitor cells. It has also been documented that children's who suffer with the heritable form of RB inherit with one of the mutated RB1 allele and in the process of developing retinal cells loss of the other allele occurs somatically. Such children's often acquire bilateral and multifocal tumors of retina which further leads to development of

\footnotetext{
* Correspondence: Mance.Heatherington779@yahoo.com

Department of Ophthalmology, Affiliated zhongshan hospital of dalian university, Jiefang Road 6, Dalian, Liao Ning 116001, China
}

some other primary tumors of bones or soft tissues in later part of their life [2]. The treatment options for RB consist of chemo-reduction by intravenous infusions, transpupillary thermotherapy, laser guided photocoagulation, orbital exenteration and radiotherapy and chemotherapy. All these treatment options are selected on the basis of location, size and stage of development of $R B$ tumor $[3,4]$. All of these multiple treatment options are associated with unwanted clinical side effects such as infection, gastrointestinal damage, fever and in extreme can cause blindness [5]. Therefore, there is a pressing demand for the development of new therapeutic agents for treating RB.

Quercetin (3,5,7,3',4'-pentahydroxyflavone) (QCT) is a flavonol present in many vegetables which is a subclass of flavonoid [6]. It can interact with a broad range of 
enzymes specifically receptor kinases, protein kinase $\mathrm{C}$, cyclin-dependent kinases (Cdks) and also with MEKERK signaling [7]. QCT is established as a chemo preventive agent in many types of cancers such as lung, cervical, prostate, breast and colon due to its antiinflammatory, anti-tumor and anti-oxidant property [8]. Number of mechanisms for its anti proliferative action are established which include 1 . Apoptosis by cell cycle arrest [9] 2. Arrest of phase $\mathrm{G}_{2} / \mathrm{M}$ or $\mathrm{G}_{1}$ [10] 3. Disruption of mitochondria and microtubules 4. Production of stress proteins 5 . Activation of caspases and 6. Release of cytochrome $C$ [11]. In addition to this it has also been found that QCT can chelate metals, scavenge oxygen free radicals, inhibit xanthine oxidase and lipid peroxidation in vitro due to its antioxidant activity [12-16].

However there are no reports exploring effects of QCT in treatment of $\mathrm{RB}$, in the present study we evaluated the molecular mechanism responsible for QCTinduced alterations in human Y79 RB cells.

\section{Methods}

\section{Cell lines and culture conditions}

The cancerous Y79 human RB cells were obtained from St. Jude Children's Res. Hosp (TN). The cancerous RB Y79 cells were cultured in RPMI-1640 medium consisting fetal bovine serum (FBS) (10\%), penicillin (1\%) and streptomycin, followed by storage at $37{ }^{\circ} \mathrm{C}$ in $5 \% \mathrm{CO}_{2}$.

\section{Reagents and antibodies}

Quercetin was obtained from Sigma-Aldrich (U.S.A), ZVAD-FMK, antibodies against p21, cytochrome c, GAPDH, caspase-9, caspase-3, cyclin D3 and p27 KIP1 were obtained from Abcam, UK. Antibodies for c-Jun N-terminal kinase (JNK), phospho-JNK, p38 MAPK, cyclin-dependent kinase-2 (CDK-2), cyclin-dependent kinase-6 (CDK-6) and phospho-p38 MAPK were received from Cell Signaling Technology, U.S.A.

\section{Cell treatment}

Quercetin for all the experiments was prepared by dissolving in dimethylsulfoxide (DMSO) from SigmaAldrich, USA, prepared freshly every time before any treatment. The prepared DMSO stock solution of QCT was used to make final defined concentrations (25$100 \mu \mathrm{M})$ in culture medium [17]. controls were prepared by preparing $0.07 \%$ solution of DMSO in culture media in all the experiments. The Y79 cells were subjected to ZVAD-FMK $(50 \mu \mathrm{M})$ for $60 \mathrm{~min}$ to inhibit the caspase activity. The Y79 cells were also treated with and without JNK inhibitor $(20 \mu \mathrm{M})$ / MAPK inhibitor p38 for 60 min followed by treatment of Quercitin $(100 \mu \mathrm{M})$ for $24 \mathrm{~h}$ prior to evaluating phosphorylation levels of JNK and p38 MAPK.

\section{Cell viability studies}

The cell viability count was done by cell counting kit (CCK; Sigma-Aldrich, U.S.A). Briefly, the Y79 cells at density of $5 \times 10^{3} /$ well were incubated along with QCT added RAPMI medium in plates containing 96-wells for $24 \mathrm{~h}$ followed by replacement of culture medium with fresh medium containing $10 \mathrm{ml}$ CCK-8 solution. The cells were incubated at $37{ }^{\circ} \mathrm{C}$ for $2 \mathrm{~h}$. the viability was calculated by recording optical density (OD) at $450 \mathrm{~nm}$.

\section{Flow cytometry for cell cycle analysis}

The Y79 cells were subjected to seeding for overnight in $10 \%$ FBS culture medium in 6 well culture plates at a density of $4 \times 10^{5}$ followed by treatment with various concentrations of QCT $(0-100 \mu \mathrm{M})$ for $24 \mathrm{~h}$. The cell cycle studies were done, briefly, the cells were treated with propidium iodide (PI) solution $(0.5 \mathrm{ml})$ followed by incubation of $30 \mathrm{~min}$ (all the procedure in accordance to manufacturer's instructions). The analysis of cell cycle distribution was done by flow cytometry (Bio-Rad, USA).

\section{Apoptosis studies by flow cytometry}

Extent of apoptosis was evaluated by Annexin-V- FITC staining using an Annexin V-fluorescein isothiocyanate apoptosis detection kit (Bio-Rad; USA) as per the manufacturer's instructions.

\section{Western blot analysis}

For western blot analysis the Y79 cells were subjected to lyses at $4{ }^{\circ} \mathrm{C}$ for $30 \mathrm{~min}$ in a buffer solution Tris buffer (50 mM, pH 8.0), sodium chloride (150 mM), EDTA (5 mM), Nonidet p-40 (1\% v/v), aprotinin $(20 \mathrm{~g} / \mathrm{mL})$, phenylmethylsulfonyl fluoride $(1 \mathrm{mM})$ and leupeptin $(25 \mathrm{~g} / \mathrm{mL})$. The protein extracts were determined using Pierce $^{\mathrm{Tm}}$ SDS-PAGE Sample Prep Kit (Thermo Scientific $\left.^{\mathrm{TM}}\right)$, followed by transfer to a polyvinylidene difluoride (PVDF) membrane. The obtained fraction was then treated with Tris- $\mathrm{HCl}$ buffer $(20 \mathrm{mM}, \mathrm{pH} 7.5)$, sodium chloride $(500 \mathrm{mM})$, non-fat milk (5\%) for $2 \mathrm{~h}$ at room temperature conditions followed by incubation with specific antibody overnight at $4{ }^{\circ} \mathrm{C}$, the blots were imaged using Immobilon Western Chemiluminescent HRP Substrate (Merck Millipore).

\section{Determination of mitochondrial membrane potential (MMP) $\left(\Delta \Psi_{\mathrm{m}}\right)$}

In the method the cells were subjected to seeding in a 6well containing plate and were treated with varying concentrations of QCT for $24 \mathrm{~h}$. The cells were washed with PBS and were stained with Rh-123 $(1 \mu \mathrm{g} / \mathrm{ml})$ for $30 \mathrm{~min}$ in the dark at $37{ }^{\circ} \mathrm{C}$. For the study mean fluorescence intensity (MFI) of treated cells was by peforming flow cytometric analysis. 


\section{Statistical analysis}

All the data are presented as the means \pm standard deviation (SD). Comparison between results was done by one-way ANOVA followed by Dunnett's test with Graphpad-prism-7 software. Value of $P<0.05$ was looked at to be a value of statistically significant.

\section{Results}

\section{Quercetin inhibited cell viability in Y79 cells}

Cell viability study was done in vitro by treating $\mathrm{RB}$ Y79 cells with different concentrations of QCT $(0,25$, $75,100 \mu \mathrm{M})$ for $24 \mathrm{~h}$. The changes in Y79 cell viability were marked by performing CCK- 8 assay. As depicted in Fig. 1, the cell viability decreased with increasing concentration of QCT compared to control cells, the results were highly significant with concentration of $100 \mu \mathrm{M}(P<0.01)$.

\section{Quercetin causes cell cycle arrest in Y79 RB cells}

Effect of QCT on cell cycle progression in Y79 RB cells was analyzed, in the process cells were treated with QCT at defined concentrations (0, $25,75,100 \mu \mathrm{M})$ for $24 \mathrm{~h}$. The cells after treatments were analyzed by flow cytometry for marking any alterations. As per the results (Fig. 2a), QCT treated RB cells after $24 \mathrm{~h}$ showed signs of inhibition in G1 phase compared to $\mathrm{S}$ and $\mathrm{G} 2 / \mathrm{M}$ phase. The molecular mechanism responsible for G1 phase arrest was assessed by analyzing the expression of various proteins by western blot analysis in Y79 cells treated with QCT $(0,50$ and $100 \mu \mathrm{M})$. On western blot studies the results (Fig. 2b and c) suggested marked reduction in expression of CDK6, CDK2 and cyclin D3 compared to control group cells, whereas the expression levels of p27 and p21 which are CDK inhibitor proteins increased after treating RB cells to QCT. The expressions of these proteins suggest involvement of cyclin-CDK pathway in QCT mediated G1 phase arrest of cell cycle in Y79 RB cells.

\section{Quercetin causes apoptosis of Y79 RB cells}

In process to evaluate involvement of apoptosis in cell viability of Y79 RB cells, we treated Y79 RB cells with varied concentrations of QCT $(0,25,75,100 \mu \mathrm{M})$ for $24 \mathrm{~h}$ followed by Annexin-V and Propidium Iodide (PI) assay. The results (Fig. 3a and b) suggested that the \% PI negative/ Annexin V positive and PI-positive/Annexin V-positive were $3.65 \%$ in control and 19.32, 35.45, $44.01 \%$ for Y79 cells treated with QCT 25, 75 and $100 \mu \mathrm{M}$ respectively. Further in order to analyze the effect of QCT on mitochondria of Y79 cells, the cells treated with QCT $9(0,25,75,100 \mu \mathrm{M})$ for $24 \mathrm{~h}$ were exposed to DiOC6 dye. The DiOC6 is a cationic lipophilic dye which accumulates specifically in the mitochondria as a property of its mitochondrial membrane potential $(\Delta \Psi \mathrm{m})$ which is reported to decrease in cells undergoing apoptosis $[18,19]$. The DiOC6 treated cells were analyzed for mean fluorescence intensity (MFI) using flow cytometry. The results of the experiment suggested a significant decrease in MFI of DiOC6 (Fig. 3c) in cells treated with QCT, highly significant results were seen in cells treated with 50 and $100 \mu \mathrm{M}$ of QCT. Overall the results suggested that treatment of QCT induced apoptosis may be due to destruction of mitochondrial membrane potential in cancerous Y79 cells.

\section{Quercetin induces the apoptosis via activation of caspases in RB Y79 cells}

Mitochondrial membrane potential (MMP) is a important factor in regulating cellular functions, any disturbances lead to alterations in membrane dynamics in response causing release of cytochrome $c$, which further leads to activation of caspase-9. In order to find whether QCT causes apoptosis mediated by release of cytochrome $c$ and caspase-9, the Y79 RB cells were treated with defined concentrations of QCT $(0,50$ and $100 \mu \mathrm{M})$ for $24 \mathrm{~h}$. The cells extracts were subjected to western blot to analyze the expression levels of caspase-9. The results of blots suggested (Fig. 4a and b) that QCT resulted in increased levels of cytochrome $c$ with

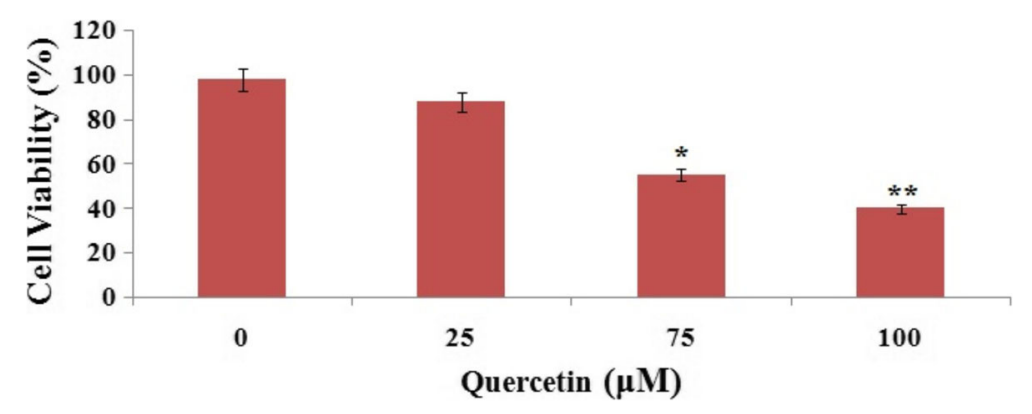

Fig. 1 Study of various concentration of Quercetin on the viability of Y79 human retinoblastoma cells in vitro. Cell viability was evaluated at various concentrations of Quercetin $(0-100 \mu \mathrm{M})$ for $24 \mathrm{~h}$. All the data are means \pm SD $(n=3)$ and are represented as percentage of control cells. ${ }^{*} P<0.05$, ${ }^{* *} P<0.01$ compared to control 


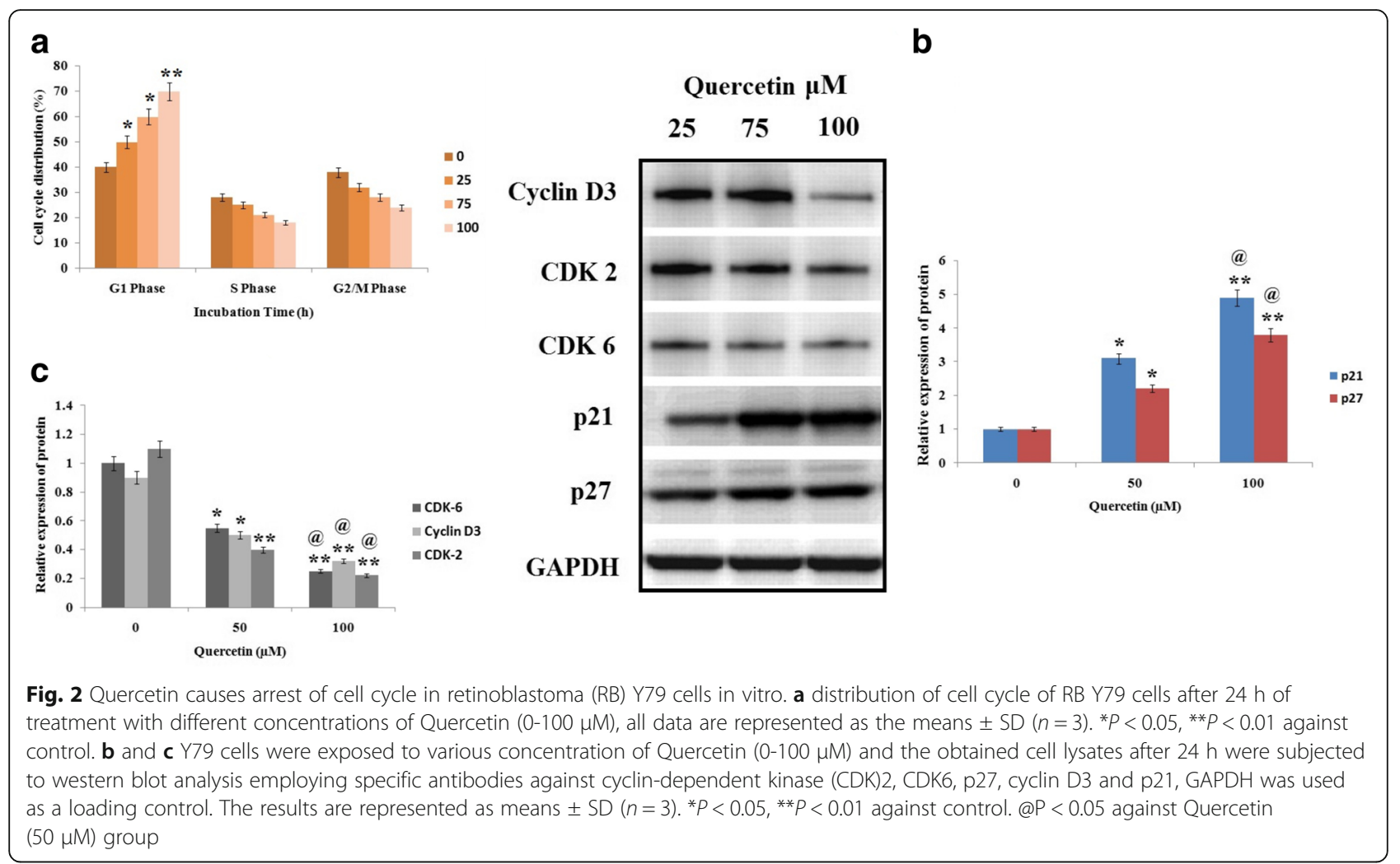

a
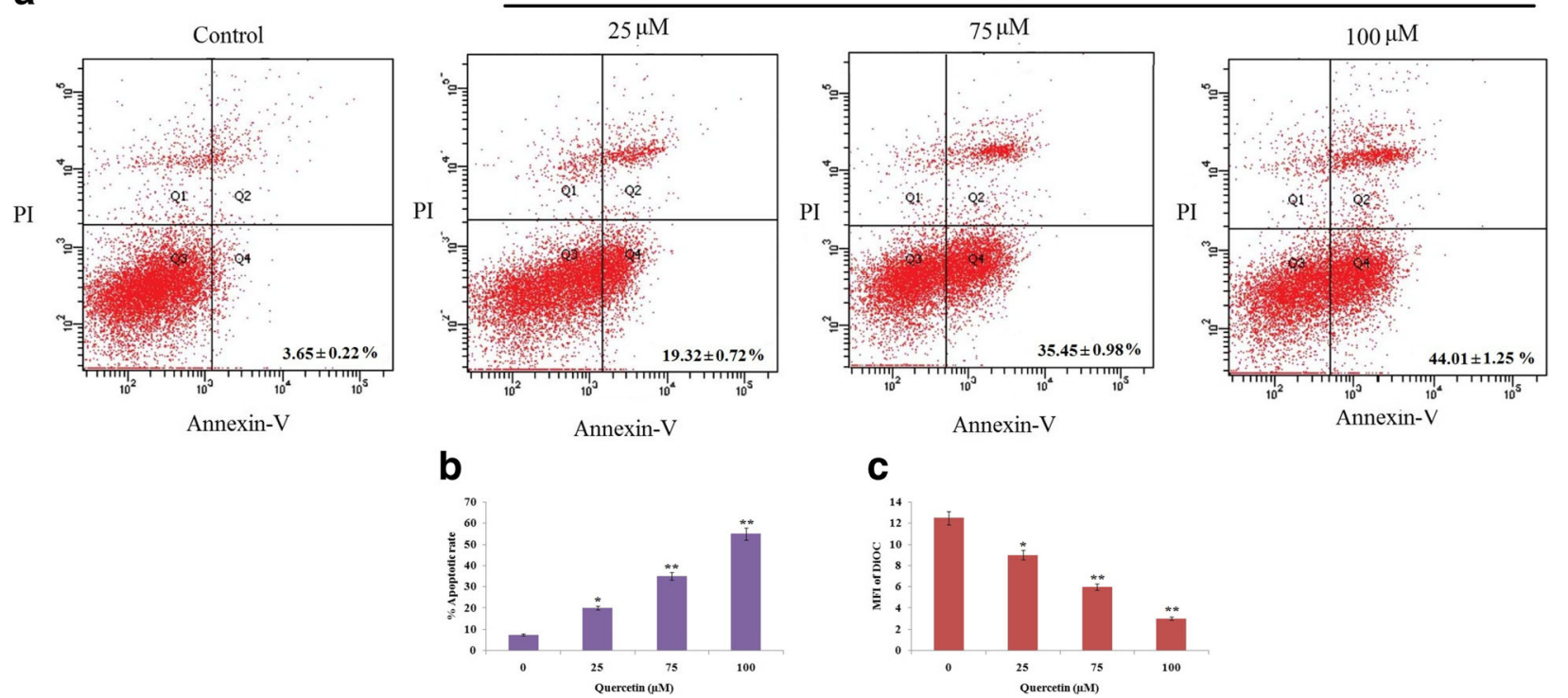

Fig. 3 Quercetin causes apoptosis of RB Y79 cells in vitro. a The control cells (untreated), the treated cells received various concentration of Quercetin (0-100 $\mu \mathrm{M})$ for $24 \mathrm{~h}$. Extent of apoptotic cells were assessed by flow cytometry subjecting cells to staining of propidium iodide (PI) and Annexin V-fluorescein isothiocyanate (FITC). b Results represent analysis of the total apoptotic cell population. All the data presented are the means $\pm \mathrm{SD}(n=3) .{ }^{*} P<0.05,{ }^{*} P<0.01$ against control. c Quercetin caused $\Delta \psi \mathrm{m}$ collapse in cancerous RB Y79 cells. Flow cytometric analysis was done in order to record the mean fluorescence intensity (MFI) of DiOC 6 . All the values are the means $\pm \mathrm{SD}(n=3) .{ }^{*} P<0.05,{ }^{* *} P<0.01$ against control 

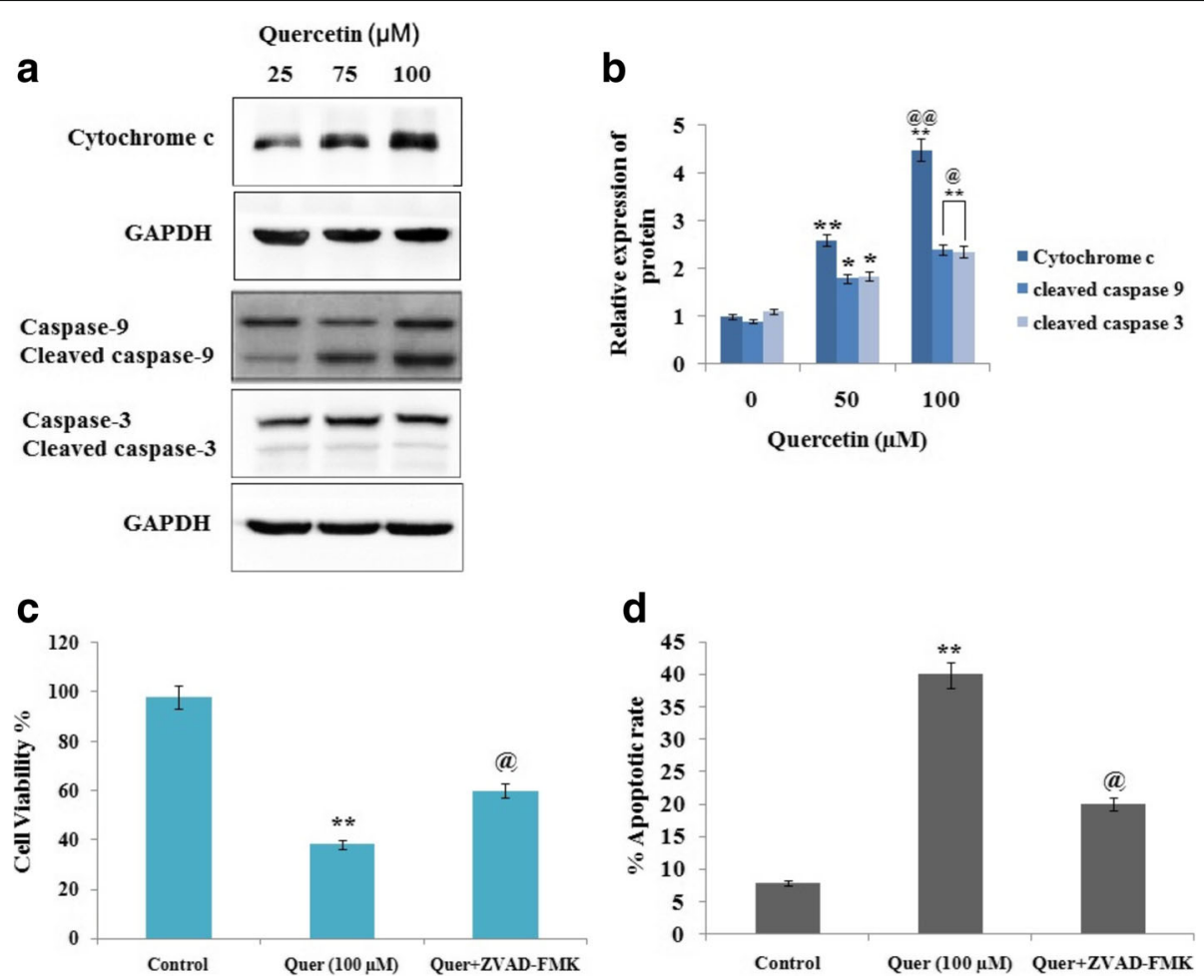

Fig. 4 Quercetin causes apoptosis of cancerous RB Y79 cells via intrinsic pathways. a and $\mathbf{b}$ The Y79 cells were exposed to Quercetin (0-100 $\mu M$ ). The obtained cell lysates after $24 \mathrm{~h}$ were analyzed by western blot using specific antibodies against caspase-9, caspase-3 and cytochrome $c$, GAPDH was used as a loading control. ${ }^{*} P<0.05,{ }^{* *} P<0.01$ against control $(n=3)$. @P $<0.05$, @@P $<0.01$ against Quercetin $50 \mu \mathrm{M}$. c Y79 cells were exposed to $100 \mu \mathrm{M}$ Quercetin for $24 \mathrm{~h}$ in the presence or absence of ZVAD-FMK. Viability of cells was done by the Cell Counting Kit-8, the data are presented as the percentage of control cells, means $\pm \mathrm{SD}(n=3),{ }^{* *} P<0.01$ against control, @P $<0.05$ against Quercetin treated group. d Quercetin exposed apoptosis was blocked by ZVAD-FMK treatment, the data presented are means \pm SD $(n=3) .{ }^{* *} P<0.01$ against control, @P $<0.05$ against Quercetin treated group

subsequent activation of caspase-3 and caspase-9 (Fig. $4 \mathrm{~b})$ with increasing doses. Further, a pan-caspase inhibitor ZVAD-FMK was used to study the effects of QCT on apoptosis of Y79 cells. Results suggested (Fig. 4c), pre treatment of the pan-caspase inhibitor (ZVAD-FMK) had attenuating effect on QCT induced decrease in Y79 viability. Results also suggested that the pan-caspase inhibitor attenuated the QCT mediated apoptotic effect on Y79 RB cells. Overall the outcomes of experiment suggested involvement of caspase activation in QCT mediated apoptosis of RB Y79 cells (Fig. 4d).

\section{Role of JNK and p38 MAPK signaling pathway in} activation of caspase- 3 and -9 induced by Quercetin

In this experiment, we evaluated the QCT treated Y79 cells for activation of JNK and p38 MAPK by western blot analysis. The results suggested (Fig. 5) that QCT resulted in increased phosphorylation of JNK and p38 MAPK in RB cells. Further in order to evaluate status of JNK and p38 MAPK in QCT mediated apoptosis, the Y79 cells were exposed to JNK-inhibitor or p38 MAPK inhibitor for $60 \mathrm{~min}$ followed by treatment of QCT $(100 \mu \mathrm{M})$ for $24 \mathrm{~h}$. The Y79 cell extracts were subjected to western blot studies for expression of proteins, as found the blots (Fig. 6) suggested QCT suppressed the activation of JNK along with p38 MAPK. The experiment also suggested significant reduction in QCT mediated apoptosis (Fig. 7c) and activation of caspase-3/-9 (Fig. 7a and b). The experimental outcomes suggest QCT mediated activation of caspase-3 and caspase-9 may be due to activation of JNK and p38 MAPK.

\section{Discussion}

Retinoblastoma is one of the most occurring intraocular cancer [20]. The treatment options available for managing RB include the chemotherapy which suffers disadvantage such as toxicity and other side effects, but still the survival rates are low in many developing countries $[21,22]$, hence becomes necessary to explore new drug molecules. QCT, a natural flavonol found in many vegetables, exerts chemo preventive action on many cancer types, such as lung, cervical, prostate, breast and colon. Number of mechanisms suggested its potential as an anticancer agent [7-16]. Although the anticancer effect of QCT is established for number of cancers, role in Retinoblastoma has not been explored. In present research 


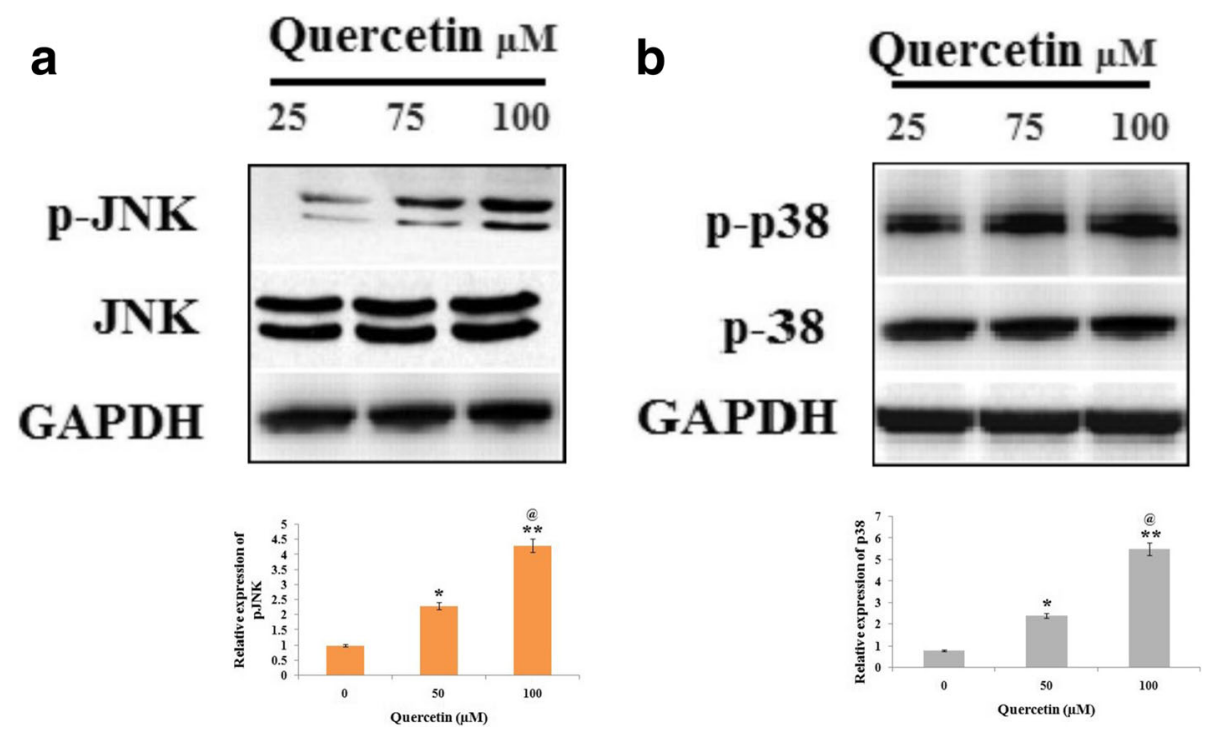

Fig. 5 Quercetin causes phosphorylation of c-Jun N-terminal kinase (JNK) and p38 mitogen-activated protein kinase (MAPK) in RB Y79 cells. a and $\mathbf{b}$ The RB Y79 cells were treated with various concentrations of Quercetin (0-100 $\mu \mathrm{M})$ and incubated for $24 \mathrm{~h}$. The levels of phosphorylated ( $p-) J N K$ and p38 MAPK were assessed by western blot, GAPDH was used as a loading control. ${ }^{*} P<0.05,{ }^{* *} P<0.01$ against control. @P $<0.05$ against Quercetin $(50 \mu M)(n=3)$

work, we evaluated the potential of QCT to be used as anticancer agent to treat RB and explored the mechanism involved by treating it with Y79 RB cells.

Results of our study outlined that QCT decreased cell viability of RB Y79 cells with increasing dose. The cell proliferation was found to mediate via regulation of cell cycle. The cell cycle is regulated by number of process, Cyclin-dependent kinases (CDKs) are activated by cyclin regulatory subunits forming complex with them $[23,24]$. Results of our study suggested QCT treatment resulted in accumulation of RB cells in g1 phase of cell cycle. We also found that treatment of QCT decreased the expression of proteins such as CDK6, cyclin D3, and CDK2, increase in expression of p27 and p21 which are CDK inhibitor proteins was observed suggesting involvement of

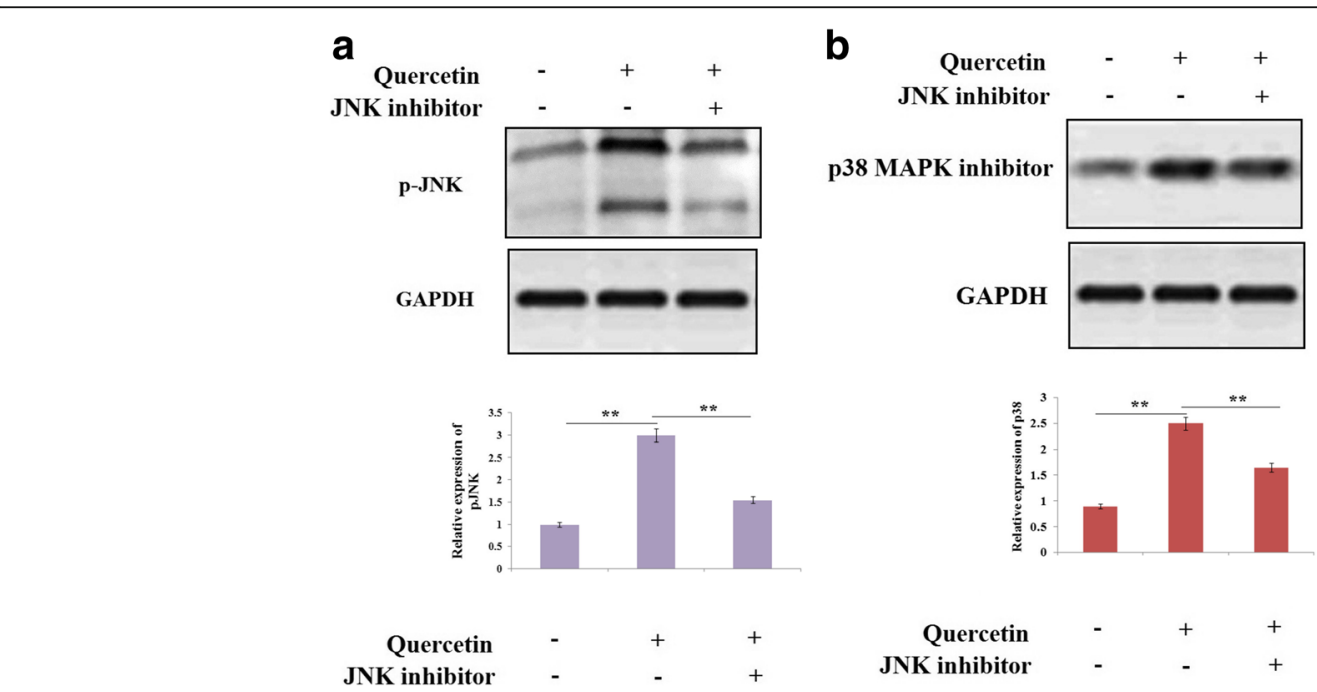

Fig. 6 Study suggesting effect of JNK and MAPK inhibitors on Quercetin-mediated activation of JNK and P38 MAPK. a and $\mathbf{b}$ The RB Y79 cells were exposed in the presence or absence of JNK inhibitor and p38 MAPK inhibitor for time period of $1 \mathrm{~h}$ followed by treatment with $100 \mu \mathrm{M}$ Quercetin for $24 \mathrm{~h}$. The levels of phosphorylation of JNK and p38 MAPK were evaluated opting western blot analysis, in which GAPDH was opted as loading control. ${ }^{* *} P<0.01(n=3)$ 


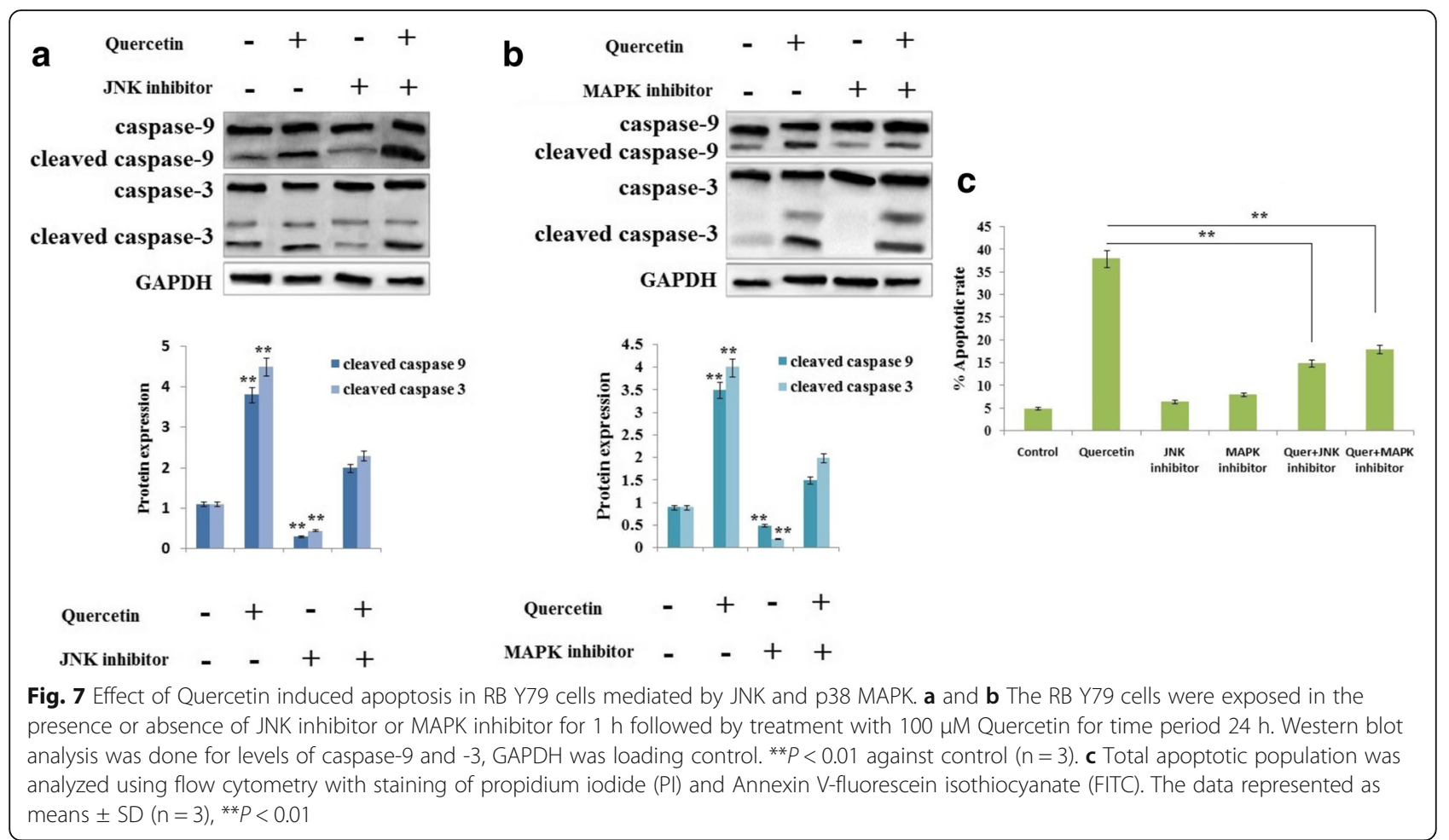

these proteins in QCT mediated arrest of G1 phase of cell cycle in Y79 RB cells.

Apoptosis is a mechanism responsible for programmed death of cells [25]. Mitochondrial membrane potential (MMP) plays an important role in activation of caspase-9 via release of cytochrome $c$ [26]. Literature confirm leading role of caspase- 9 and caspase- 3 in apoptosis [27, 28]. Outcomes of our study revealed that Quercetin caused increase in MMP leading to activation of caspase-dependent apoptotic pathway of mitochondria. Also we confirmed involvement of caspase-9 and caspase-3 in apoptosis, by treating Y79 cells with a pan-caspase inhibitor ZVAD-FMK followed by exposing them to QCT. Experiments were carried to evaluate role of JNK and p38 MAPK pathways in Querectin mediated apoptosis of Y79 RB cells. Results suggested QCT resulted in activation of JNK and p38 MAPK in cancerous Y79 cells. The activation of caspase- 9 and caspase- 3 was suppressed in Y79 cells treated with JNK and p38 MAPK inhibitor leading to decrease in Querectin-mediated apoptosis. Overall the results directed involvement of JNK and p38 MAPK pathways in Querectin mediated apoptosis of Y79 RB cells by regulating expressions of caspase-9/-3.

\section{Conclusion}

In conclusion, the present research confirmed that QCT exerted anticancer effect on RB Y79 cells by inducing apoptosis and cell cycle arrest. These findings propose a novel therapeutic approach for treatment of $\mathrm{RB}$ which needs further clinical investigation.

\section{Abbreviations \\ CDK: Cyclin-dependent kinase; JNK: c-Jun N-terminal kinase; MAPK: p38 mitogen-activated protein kinase; QCT: Quercetin; RB: Retinoblastoma}

\section{Acknowledgments}

We express thanks to the management and staff of Department of Ophthalmology, Affiliated Zhongshan hospital of Dalian university, China for providing necessary facilities.

\section{Funding}

The work was self-financed and hence we declare no acknowledgments for any funding agency.

\section{Availability of data and materials}

All the summarized data is presented in paper. The raw data of the present research is a under ethics restriction and is not presented here.

\section{Authors' contributions}

Haojie Liu, Ming Zhou both have contributed equally to the work. The data were recorded by Haojie Liu, Ming Zhou and analyzed together. Both the authors prepared the manuscript and have finalized the manuscript. Both authors read and approved the final manuscript.

Ethics approval and consent to participate

As there were no animals involved in the study hence ethics committee recommendations were not needed.

Consent for publication

Not applicable.

Competing interests

The authors declare that they have no competing interests. 


\section{Publisher's Note}

Springer Nature remains neutral with regard to jurisdictional claims in published maps and institutional affiliations.

Received: 30 June 2017 Accepted: 20 November 2017

Published online: 13 December 2017

\section{References}

1. Vogel F. Genetics of retinoblastoma. Hum Genet. 1979:52:1-54.

2. Eng C, Li FP, Abramson DH, Ellsworth RM, Wong FL, Goldman MB, et al. Mortality from second tumors among long-term survivors of retinoblastoma. J Natl Cancer Inst. 1993;85:1121-8.

3. Eagle RC Jr. The pathology of ocular cancer. Eye (Lond). 2013;27:128-36.

4. Dimaras H, Kimani K, Dimba EA, Gronsdahl P, White A, Chan HS, Gallie BL. Retinoblastoma. Lancet. 2012;379:1436-46.

5. Hsiao WT, Tsai MD, Jow GM, Tien LT, Lee YJ. Involvement of Smac, p53, and caspase pathways in induction of apoptosis by gossypol in human retinoblastoma cells. Mol Vis. 2012;18:2033-42.

6. Csokay B, Prajda N, Weber G, Olah E. Molecular mechanisms in the antiproliferative action of quercetin. Life Sci. 1997:60(24):2157-63.

7. Nguyen TT, Tran E, Nguyen TH, Do PT, Huynh TH, Huynh H. The role of activated MEK-ERK pathway in quercetin-induced growth inhibition and apoptosis in A549 lung cancer cells. Carcinogenesis. 2004;25(5):647-59.

8. Hertog MG, Hollman PC, Katan MB, Kromhout D. Intake of potentially anticarcinogenic flavonoids and their determinants in adults in The Netherlands. Nutr Cancer. 1993:20:21-9.

9. Lee TJ, Kim OH, Kim YH, Lim JH, Kim S, Park JW, Kwon TK. Quercetin arrests G2/M phase and induces caspase-dependent cell death in U937 cells. Cancer Lett. 2006;240:234-42.

10. Ong CS, Tran E, Nguyen TT, Ong CK, Lee SK, Lee JJ, Ng CP, Leong C, Huynh H. Quercetin-induced growth inhibition and cell death in nasopharyngeal carcinoma cells are associated with increase in bad and hypophosphorylated retinoblastoma expressions. Oncol Rep. 2004;11:727-33.

11. Yoshizumi M, Tsuchiya K, Kirima K, Kyaw M, Suzaki Y, Tamaki T. Quercetin inhibits Shc- and phosphatidylinositol 3-kinase-mediated c-Jun N-terminal kinase activation by angiotensin $\|$ in cultured rat aortic smooth muscle cells. Mol Pharmacol. 2001:60:656-65.

12. Kandaswami C, Middleton E. Jr free radical scavenging and antioxidant activity of plant flavonoids. Adv Exp Med Biol. 1994;366:351-76.

13. Bors W, Heller W, Michel C, Saran M. Flavonoids as antioxidants: determination of radical-scavenging efficiencies. Methods Enzymol. 1990; 186:343-55.

14. Bors W, Michel C, Saran M. Flavonoid antioxidants: rate constants for reactions with oxygen radicals. Methods Enzymol. 1994:234:420-9.

15. da Silva EL, Piskula MK, Yamamoto N, Moon JH, Terao J. Quercetin metabolites inhibit copper ion-induced lipid peroxidation in rat plasma. FEBS Lett. 1998;430:405-8.

16. Vulcain E, Goupy P, Caris-Veyrat C, Dangles O. Inhibition of the metmyoglobin-induced peroxidation of linoleic acid by dietary antioxidants: action in the aqueous vs. lipid phase. Free Radic Res. 2005;39:547-63.

17. Vijayababu MR, Kanagaraj P, Arunkumar A, llangovan R, Aruldhas MM, Arunakaran J. Quercetin-induced growth inhibition and cell death in prostatic carcinoma cells (PC-3) are associated with increase in p21 and hypophosphorylated retinoblastoma proteins expression. J Cancer Res Clin Oncol. 2005;131(11):765-71.

18. Guo Y, Zhang W, Yan YY, Ma CG, Wang X, Wang C, Zhao JL. Triterpenoid pristimerin induced HepG2 cells apoptosis through ROS-mediated mitochondrial dysfunction. J Buon. 2013;18:477-85.

19. Shao Q, Zhao X, Yao L. Matrine inhibits the growth of retinoblastoma cells (SO-Rb50) by decreasing proliferation and inducing apoptosis in a mitochondrial pathway. Mol Biol Rep. 2014:41:3475-80.

20. Pandey AN. Retinoblastoma: an overview. Saudi J Ophthalmol. 2014;28:310-5.

21. Sarici A, Kizilkilic O, Celkan T, Gode S. Blue toe syndrome as a complication of intra-arterial chemotherapy for retinoblastoma. JAMA Ophthalmol. 2013;131:801-2.

22. Suesskind D, Schrader M, Foerster MH, Ernemann U, Aisenbrey S. Cataract formation: a possible complication of intra-arterial chemotherapy for retinoblastoma. Eur J Ophthalmol. 2014;24:449-53.

23. Sherr CJ. Cancer cell cycles. Science. 1996;274:1672-7.

24. Jacks T, Weinberg RA. Cell-cycle control and its watchman. Nature. 1996:381:643-4
25. Cao A, Li Q, Yin P, Dong Y, Shi H, Wang L, Ji G, Xie J, Wu D. Curcumin induces apoptosis in human gastric carcinoma AGS cells and colon carcinoma HT-29 cells through mitochondrial dysfunction and endoplasmic reticulum stress. Apoptosis. 2013;18:1391-402.

26. Gupta S, Kass GE, Szegezdi E, Joseph B. The mitochondrial death pathway: a promising therapeutic target in diseases. J Cell Mol Med. 2009;13:1004-33.

27. Huang YC, Kuo CL, Lu KW, Lin JJ, Yang JL, Wu RS, Wu PP and Chung JG. 18a-glycyrrhetinic acid induces apoptosis of HL-60 human leukemia cells through caspases - and mitochondria-dependent signaling pathways. Molecules. 2016; 21(7):pii: E872.

28. Jiang YQ, Chang GL, Wang Y, Zhang DY, Cao L, Liu J. Geniposide prevents hypoxia/reoxygenation-induced apoptosis in $\mathrm{H} 9 \mathrm{c} 2$ cells: improvement of mitochondrial dysfunction and activation of GLP-1R and the PI3K/AKT signaling pathway. Cell Physiol Biochem. 2016;39:407-21.

\section{Submit your next manuscript to BioMed Central and we will help you at every step:}

- We accept pre-submission inquiries

- Our selector tool helps you to find the most relevant journal

- We provide round the clock customer support

- Convenient online submission

- Thorough peer review

- Inclusion in PubMed and all major indexing services

- Maximum visibility for your research

Submit your manuscript at www.biomedcentral.com/submit
Biomed Central 